\title{
How International Trade Affects the Spatial Pattern of China's Economic Activities?
}

\author{
Yanling Zhu \\ Department of Economics, Jinan University, Guangzhou, China \\ Email:m13250712644@163.com
}

How to cite this paper: Zhu, Y.L. (2019) How International Trade Affects the Spatial Pattern of China's Economic Activities? American Journal of Industrial and Business Management, 9, 627-646. https://doi.org/10.4236/ajibm.2019.93043

Received: February 25, 2019

Accepted: March 19, 2019

Published: March 22, 2019

Copyright ( 2019 by author(s) and Scientific Research Publishing Inc. This work is licensed under the Creative Commons Attribution International License (CC BY 4.0).

http://creativecommons.org/licenses/by/4.0/ (c) (i) Open Access

\begin{abstract}
This paper has analyzed the impact of international trade mechanisms to spatial economic structure, panel data 2001-2016 China's 30 provinces, and factors which affect Chinese economic structure of empirical research on trade openness, and found that, on the whole, trade openness has no significant direct effect on China's economic spatial pattern, and indirectly promotes policy advantages to make economic activities more spatially agglomerate, and to make economic activities more dispersed by promoting transportation infrastructure. From the perspective of the East, Central and West regions, the trade openness directly promotes the agglomeration of the East and West regions. The regional policy advantage is the main mechanism affecting the regional economic agglomeration. The human capital mechanism and the transportation infrastructure mechanism in the eastern region respectively make dispersal and agglomeration; the transportation infrastructure in the central part makes the space more dispersed; the human capital mechanism and the transportation infrastructure mechanism in the western region respectively make the space agglomerate and decentralized. Local governments should strengthen regional cooperation and formulate differentiated trade policies to lead regional industries to drive regional innovation.
\end{abstract}

\section{Keywords}

International Trade, Economic Spatial Pattern, Trade Openness

\section{Introduction}

2009 World Bank statistics show that Shanghai's per capita GDP in 2007 is equivalent to the level of the United Kingdom in 1988, and Guizhou is only equivalent to the level of the United Kingdom in 1930, economic activity is more concentrated in the coastal cities. [1] cited data from China 1985-1990, and 
found that after the reform and opening up, China's economic activities, in particular industrial production quickly gathered to the coastal areas, and the income gap between regions also expanded in emerging countries such as Brazil which has similar economic phenomenon [2]. With the development of globalization and economic integration, China's economy is increasingly connected with the world economy. The spatial pattern of economic activities reflects the changes of a country's economic development. Therefore, it is necessary to think about how international trade affects China's economic spatial pattern.

The spatial pattern of China's international trade and economic activities is dynamic and consistent in time and space. Reform and opening up has opened the door of China to the outside world and has also driven the rapid development of China's economy. The development of international trade has made China's economic activities spatially changed [3]. So, what extent is China's economic spatial pattern affected by foreign trade? What is the internal mechanism of this influence? In international trade, location and physical geography attribute areas are endogenous, the area near the international markets more easily gather, [4] general equilibrium framework, found that location can at least explain $20 \%$ of the income changes of the United States. What is the difference between the impact of foreign trade on the economic spatial pattern in different regions? Studying these issues will help each region to formulate differential trade policies and regulate the spatial layout of economic activities in the region.

\subsection{Literature Review}

\subsubsection{Theoretical Research}

Based on comparative advantage, traditional trade theory analyzes trade between countries or regions, and trades produce products with comparative advantages, and gradually realize the specialization of product production and improve the production level and welfare of the whole society. The difference in resource endowment leads to the specialization of the division of labor between enterprises, which lead to the division of labor and cooperation between different industries, which provide a theoretical basis for the agglomeration of different industries. The neoclassical trade theory introduces the factor endowment theory based on the comparative advantage theory and provides a relatively dynamic trade model. These trade theories explain the reasons for the trade in the region, and the spatial layout caused by the trade countries is not further explored.

International trade and regional economics were two relatively independent disciplines at the time of their initial development. With the continuous development of globalization and trade liberalization, research on spatial agglomeration under the open environment came into being. Based on regional heterogeneity, [5] analyzed the urban spatial distribution of small open economies and used the urban-systems model to find that economic openness depends on geographical features. Different geographical locations result in different economic activities in the region affected by the international market and the domestic 
market. The coastal areas have comparative advantages in location and enjoy a higher degree of trade openness. The distribution of economic activities is ultimately close to the international market and far from competition. A balance is achieved [6] [7].

Based on the New Trade Theory, [8] introduced the "iceberg cost" to link trade economics with regional economics, providing a bridge between the two, from the new trade theory (New Trade Theory). To New Economic Geography, spatial factors have become an important factor affecting international trade and spatial agglomeration. [9] believes that transportation costs affect the location of the manufacturing industry. Under the combined effect of economies of scale and market share, the manufacturing industry will eventually form a central-peripheral structure. Some enterprises choose "peripheral" areas close to the advantages of natural resources in order to avoid competition in "central" areas, while some enterprises gather in the "central" area for greater market and economies of scale.

[10] extended the new economic geography model. Through the forward-looking relationship of the production chain, it shows that the generation of international trade will reduce the urban concentration, which leads to the spatial dispersion of domestic economic activities. However, this theory cannot explain which enterprises will gather and which enterprises will spread outwards in the actual application process. Until [11] proposed that corporate heterogeneity has an impact on trade structure, scholars can face the agglomeration and diffusion behavior of individual enterprises from the micro level, and the emergence of international trade, so that high-productivity enterprises choose to export, and sub-productivity enterprises will choose domestic market, low. Productivity companies will eventually exit the market. The emergence of trade has re-shuffled the enterprise, and the industry has spontaneously reorganized. The difference in the state of trade of enterprises has also determined the spatial pattern of enterprises. Export enterprises are gradually approaching the international market, and domestic enterprises are gathering in the domestic market, showing varying degrees.

\subsubsection{Empirical Research}

[6] [10] found that trade liberalization will reduce the city's first industrial concentration degree, economic activity is more dispersed in the urban space, is conducive to narrowing the income gap among and within the regions. Some scholars have the opposite conclusions, pointing out that global trade will drive economic activities to some regions. Regional heterogeneity makes some regions have the geographical advantage of foreign trade, so that economic activities are redistributed among different regions, and finally gradually approaching the regional agglomeration of international market [12].

The results of empirical research vary according to the choice of angles. The existing researches have mainly carried out analysis and research from the perspectives of global, national and urban, but have not reached a consensus conclu- 
sion. Some scholars have studied the impact of globalization on the industrial division of labor between different countries, and the international economic integration has changed the global economic structure. [13] found that there is a negative correlation between urban concentration and trade openness. And empirical analysis found that the influence of trade openness on urban concentration is independent of urbanization, that is, it does not mean that more open cities are more spilled than non-open cities from the concentrated areas [7]. [14] used the data of 110 countries from 1970-2000, It did not find that the openness of foreign trade had a significant impact on urban concentration. On the basis of this, [15] expanded to 168 countries, and found that countries with larger market scales will have more economic activities when trade liberalization deepens, while countries with smaller domestic market sizes are more dispersed.

From a national perspective, [16] found that the Mexican industry continued to shift to the North American border between 1975 and 1997, and the urban concentration of large internal cities gradually declined. [17] used Indonesia as an example to find out that the trade system and national settlement space allocation have a great impact on industrial space concentration. The impact of tariffs and other trade policies not only affect the behavior of the current business, with the slow adjustment of capital to promote changes in agglomeration economies, trade protectionism triggered by the impact of trade policies also have effects of longer period [18]. [19] showed when companies face complex international market, they will close to the same target market as companies, which called destination agglomeration phenomenon, [20] used Chinese industrial enterprise database from 2000 to 2006, the data confirms that this phenomenon also exists in China. On the one hand, geographical proximity can enjoy more spillover effects; on the other hand, proximity to international markets is conducive to saving trade costs [21].

[22] used panel data from 1987 to 2001 to explore the influencing factors of industrial agglomeration in China, indicating that economic openness promotes the spatial agglomeration of Chinese industry, while opening up is influenced by geographical and historical factors. [23] uses urban-level employment and production data to find that trade openness has a positive impact on population spatial agglomeration. [24] using the difference between the real wage variable region as a measure of regional agglomeration, which has also been a positive correlation. [12] takes American manufacturing as an example, pointing out that the spillover effect of international trade is related to the regional level, and knowledge spillover only promotes the zip code regional level. After reform and opening up and joining the WTO, China has made international trade a period of rapid development, coastal areas gathered a large number of enterprises so that enterprises have a significant spatial pattern change [25]. From the perspective of micro-enterprise data, globalization has a greater impact on the spatial distribution of China's economic activities [26], and both data analysis and map simulations indicate the agglomeration of imports and exports in coastal areas, and the manufacturing industry as a whole is concentrated in the eastern coastal 
areas [27]. [28] analyzes the influence of regional advantages and industrial superiority mechanism on regional industrial agglomeration under continuous space, and conducts empirical tests with China's 1998-2007 provincial data. The study finds that international trade drives the Chinese economy to coastal areas.

From a city perspective, [29] first explored the agglomeration differences within regions. Scholars used the import and export data of the six regions of Colombia in 1999-2010 to find that regional trade openness in regions with higher trade levels would promote regional agglomeration. The lower the level of trade, the degree of trade openness will make the region appear to be spatially dispersed. [30] studied the data of the eastern coastal areas, the middle reaches of the Yellow River and Yangtze River and the northwestern from 2005-2011. It was found that the export trade promoted the agglomeration of the eastern coastal areas and some central cities, but there was no significant correlation with the concentration of western cities. [31] used the changes of the Theil Index of the provinces from 2001 to 2010, found that the relationship between economic agglomeration and international trade of the whole country and the eastern region was positively $t$ " type, while the central and western regions had no significant correlation. [32] analyzed the spatial agglomeration evolution of 19 double-digit manufacturing industries in the province from 1980 to 2011, and found that labor-intensive industries are mostly export-oriented, and most of them concentrated in the eastern coastal areas.

Most scholars use individual fixed-effect models to explore the direct effects of trade openness on regional agglomeration. [33] constructed an econometric model containing the interaction between regional and industrial characteristics when studying European industrial distribution, which can reflect the comparative advantages of industries in different regions. [34] [35] used this model for China's regional, the comparative advantages of agglomerated industries have been explored, but this method cannot distinguish whether foreign trade has an impact on the economic spatial pattern through regional and industrial differences. [36] and [37] use the cross-terms of trade openness and different control variables to explore their indirect effects through different mechanisms of action.

In the study of the relationship between foreign trade and economic spatial pattern, there are relatively many theoretical studies and empirical studies abroad, mainly by exploring the impact of foreign trade on regional agglomeration or dispersion, thus reflecting the regional spatial distribution of economic activities. There are few domestic empirical studies on this aspect, and there is a lack of articles that take into account spatial geography between regions. At this stage, globalization and economic integration are developing rapidly, and the improvement of infrastructure has also brought about closer economic ties between regions. The economic growth and industrial agglomeration of various provinces and cities have obvious spatial effects [38]. The studies about the influence of trade openness on spatial agglomeration, no consideration of spatial factors will cause some bias in the estimation results. On this basis, the paper 
uses data of 30 provinces from 2001-2016, to explore the impact of foreign trade on China's economic spatial pattern. The empirical model of this paper draws on the empirical experience of [36] and [37], introducing the cross-items of trade openness and regional protectionism, foundation and facilities, human capital, which are used to explore the mechanism of trade openness on China's spatial agglomeration, and then construct the spatial Dubin model and spatial lag model. At the same time, based on the comparative advantages of location, this paper studies the economic spatial pattern of foreign trade in the eastern, central and western regions.

\section{The Status Quo of China's Foreign Trade and Economic Spatial Pattern}

\subsection{The Status Quo of Foreign Trade and China's Economic Growth}

In recent years, China's foreign trade grew rapidly, accounting for more and more share in international trade, according to WTO data show that the world's total trade in 2002 was $\$ 13.109$ (data from China Statistical Yearbook) trillion, China import and export trade volume was $\$ 620.8$ billion, only $4.7 \%$ of the world; and the world's total trade in 2016 was $\$ 32.18$ trillion, China was $\$ 3.6856$ trillion, the proportion of the world reached $11.45 \%$, in 2002 relative increase of nearly 6.75 percentage points. At the same time, China's GDP has also increased rapidly, total imports and exports remained upward trend is also growing GDP and GDP growth and export share of GDP remained the same trend. In 2007, the total imports and exports accounted for the largest proportion of GDP. At this time, the GDP growth rate also reached the maximum. After 2010, both showed a downward trend. This shows that China's economic growth has an inseparable relationship with foreign trade.

In 2016, only 10 provinces on the eastern coast of the country account for $18.35 \%$ of the country's land area. It has a population of $39.89 \%$ of the country, and its total import and export reached 287.357 billion dollars, accounting for $78 \%$ of the country's total import and export. In 2003-2016, the total import and export of the 10 provinces on the eastern coast has a slight decline, but the total amount is above $75 \%$. The eastern coastal provinces are the center of China's foreign trade. In addition, the eastern coastal areas are not only the international hub of China's foreign trade, but also occupy a very important position in economic development. It is found that the regional GDP of the 10 provinces in the eastern coastal areas accounts for more than $50 \%$ of the national. Moreover, China's three major urban agglomerations (Beijing-Tianjin-Hebei City Group, the Yangtze River Delta City Group and Pearl River Delta City Group) covers most of the eastern part of the city, so that the eastern part of our country is the center of economic concentration.

\subsection{The Status Quo of China's Economic Spatial Pattern}

The economic spatial pattern refers to the distribution of economic activities in a 
certain region, mainly represented by the agglomeration and dispersion of economic activities. This paper represents the spatial pattern of each province by measuring the degree of regional economic agglomeration. The agglomeration index is mostly used to measure the concentration of the industry. The object of this study is mainly the spatial layout of economic activities in the whole region. Therefore, the spatial Gini coefficient proposed by [9] is used. The specific formula is as follows:

$$
G=\frac{1}{2 n^{2} \mu_{y}} \sum_{i=1}^{n} \sum_{j=1}^{n}\left|y_{i}-y_{j}\right|
$$

Among that, $\left|y_{i}-y_{j}\right|$ indicates the absolute value of the difference in the output value of two prefecture-level cities in any province. $n$ is the number of prefecture-level cities in a province. $\mu_{y}$ is the average output value of the provincial and cities, $G$ is the space Gini coefficient for the provinces and cities. The spatial Gini coefficient is between [0,1], and the closer to 1 is, the more concentrated the economic activities in the region are, and the more uneven the spatial distribution of economic activities in cities and towns within the provinces and cities. The GDP data of prefecture-level cities are derived from the China Regional Statistical Yearbook and the statistical yearbooks of various cities. Shanghai, Beijing, Chongqing, and Tianjin are all measured by the jurisdictions, and some data about prefecture-level cities and county units of the calculations are excluded.

The spatial Gini coefficient shows that the spatial Gini coefficient is the highest in Beijing, the spatial distribution of economic activities is relatively concentrated, and the degree of agglomeration increases with time. Among the provinces with an average Gini coefficient of more than 0.4 in space between 2001 and 2016, except Guangdong and Beijing, other provinces are located in the central and western regions. The overall economy of Guangdong Province is relatively developed, but due to geographical conditions, the development gap of Northwest Guangdong and Pearl River Delta region is relatively large, and the economic activities are more concentrated in the Pearl River Delta region. Therefore, the development gap between the regions is large, and the spatial Gini coefficient is relatively large.

Eastern spatial Gini coefficient tends to decrease, since the beginning of 2010, the spatial Gini coefficient is less than 0.36; central and western regions showed significant upward trend, West area from 2003 to 2015, an increase of 0.38 to 0.4031 , further trend of regional economic gathering, the western region's economic development stage, and because of the special nature of economic activity and geographical conditions are often more than a certain distribution of several cities in the western provinces And the spatial Gini coefficient shows that the economic agglomeration of the central and western provinces and cities has increased year by year. The vertical number shows that the western economic agglomeration is higher than that of the central and eastern regions. In the eastern region, the economy is gradually dispersed, and the Gini coefficient between the 
central and western regions is getting larger and larger. It can be seen that the differences and trends in China's economic agglomeration mainly come from the differences in economic distribution between the eastern, central and western regions and within the central and western regions.

\section{The Model Settings and Data Description}

\subsection{Setting of Spatial Measurement Model}

Based on the measurement model built by [37], this paper explores the impact mechanism at the provincial level, and uses the intersection of human capital, regional protectionism, infrastructure and trade openness to explore the role of trade openness in the economy. The internal mechanism of the activity, the basic measurement model of this paper is as follows:

$$
\begin{aligned}
& \operatorname{InAgg}_{i t}=\beta_{0}+\beta_{1} \text { InOpen }_{i t}+\beta X_{i t}\left(1+\operatorname{InOpen}_{i t}\right)+\varepsilon_{i t} \\
& \beta X_{i t}\left(1+\text { InOpen }_{i t}\right)=\beta_{2} \text { InHum }_{i t}+\beta_{3} \text { InGov }_{i t}+\beta_{4} \text { InTransp }_{i t}+\beta_{5} \text { InMp }_{i t} \\
& +\beta_{5} \text { InDis }_{i t}+\beta_{6} \text { InOpen }_{i t} * \text { InHum }_{i t}+\beta_{7} \text { InOpen }_{i t} * \operatorname{InGov}_{i t} \\
& +\beta_{8} \text { InOpen }_{i t} * \text { InTransp }
\end{aligned}
$$

Among that, InAgg $g_{\text {it }}$ is the agglomeration index for each province over the years, expressed as the spatial Gini coefficient; InOpen $_{i t}$ is trade openness, $X_{i t}$ is the control variable matrix, $\beta$ is a variable coefficient matrix, Gov ${ }_{i t}$ stands for regional protectionism, the ratio of corporate income tax on fiscal revenue of each province and city divides the ratio of GDP of each city within the province; InTransp $_{i t}$ is the number of highway mileage per unit area, expressed as the level of infrastructure in the provinces over the years; $I n M p_{i t}$ is the domestic potential market scale; InDis $s_{i t}$ indicates the distance from each province to the nearest port; $\beta_{6}$ to $\beta_{8}$ are coefficients about the explanatory variables which are the cross-terms of the logarithm of the trade openness with the logarithm of human capital, regional protectionism and the infrastructure level. $\varepsilon_{i t}$ is a stochastic disturbance item.

The spatial error model (SEM) is mainly applied to the spatial autocorrelation of dissipative terms, which indicates that the spatial correlation of trade openness is an important factor affecting the spatial agglomeration of economic activities. To exclude non-systematic spatial correlation, the specific model is as follows:

$$
\begin{gathered}
\operatorname{InAgg}_{i t}=\beta_{0}+\beta_{1} \text { InOpen }_{i t}+\beta X_{i t}\left(1+\text { InOpen }_{i t}\right)+\mu \\
\mu=\lambda W_{i j} \mu+\varepsilon_{i t} \varepsilon_{i t} \sim N\left(0, \delta^{2} I_{n}\right)
\end{gathered}
$$

The spatial lag model (SLM) is the correlation of space explanatory variables and the dependent variable, indicating that the area affected by the variables of the surrounding areas, in the performance of space-related variables, with a clear space effects between our various provincial overflow, especially the development of China's economic belt and urban circle, have made the economic ties between the provinces and neighboring provinces increasingly strengthened, 
and the spatial agglomeration of provinces and cities is affected by the surrounding provinces and cities. At the same time, the opening of international trade is also affected by the surrounding trade environment. When the model is set, this paper considers the spatial lag model of the explanatory variables. The model is as follows:

$$
\begin{aligned}
\text { InAgg }_{i t}= & \beta_{0}+\beta_{1} \text { InOpen }_{i t}+\beta X_{i t}\left(1+\text { InOpen }_{i t}\right) \\
& +W_{i j} * \rho\left[\beta_{1} \text { InOpen }_{i t}+\beta X_{i t}\left(1+\text { InOpen }_{i t}\right)\right]+\varepsilon_{i t}
\end{aligned}
$$

Among that, $\mu$ is the interference item, $\rho, \lambda$ is the spatial autocorrelation coefficient, $\varepsilon_{i t}$ is the white noise, $W_{i j}$ is the spatial correlation matrices, this paper uses the linear distance between regions as matrix elements.

\subsection{Variable Definition and Data Description}

\subsubsection{Trade Openness}

Trade openness refers to the openness of a regional trade level. Scholars such as [39] have studied the indicators of trade openness, and adopted five indicators: foreign trade dependence, actual tariff rate, foreign exchange market distortion and price difference. Actual situation in China shows that foreign trade dependence is the most reasonable comprehensive indicator to measure China's trade openness. Foreign trade dependence refers to the total import and export volume of each region as a share of GDP or national income. The specific calculation formula is as follows:

$$
\text { openness }_{i, t}=\frac{\text { export }_{i, t}+\text { import }_{i, t}}{G D P_{i . t}}
$$

As a comprehensive indicator, on one hand, foreign trade dependence can reflect the ability of each region to use the international market. On the other hand, it can also reflect the degree of influence of various regions in the international economic fluctuations, and can provide an objective measure of the regional foreign economic structure (Zhang, $\mathrm{Wu}, 2011$ ). The total import and export data of various provinces and cities are derived from the China Regional Statistical Yearbook and the statistical yearbooks of various provinces and cities. The regional GDP of each province and city comes from the China Statistical Yearbook. The US dollar exchange rate is derived from the China Economic and Social Development Statistics Database.

\subsubsection{Other Control Variables}

This paper selects the data of various provinces and cities in China from 2000 to 2016, introduces the mechanism of infrastructure level, regional protectionism and human capital in the model, and selects the port distance and domestic market potential as the indicators of stability. The specific indicators are described in Table 1 shown as follows:

Infrastructure level $\left(\right.$ Transp $\left._{i t}\right)$. When the level of domestic infrastructure is high, the transportation cost is low, and enterprises will tend to be close to the consumer market. [37] simulates the impact of trade openness on economic 
Table 1. Independent variable definition and description.

\begin{tabular}{|c|c|c|c|c|c|}
\hline Variable & Name & Measurement and assignment & Mean & Min & $\operatorname{Max}$ \\
\hline Openness to the outside world & Open $_{i t}$ & $\begin{array}{l}\text { Total import and export volume is higher than the total } \\
\text { GDP of the provinces and cities }\end{array}$ & 0.317 & 0.032 & 1.698 \\
\hline Human capital & Hum $_{i t}$ & $\begin{array}{l}\text { The number of students in the school of ordinary } \\
\text { institutions of higher learning than the resident } \\
\text { population/per } 100,000\end{array}$ & 1521.8 & 277.58 & 3489.75 \\
\hline Infrastructure level & Transp $_{i t}$ & Highway mileage is higher than the provincial area & 0.700 & 0.032 & 2.438 \\
\hline Domestic market potential & $M p_{i t}$ & Domestic market potential indicator & 352.41 & 10.75 & 2117.1 \\
\hline Distance from the port & Dis $_{i t}$ & $\begin{array}{l}\text { Distance from the nearest port of the provincial capital } \\
\text { city } / \mathrm{km}\end{array}$ & 616.91 & 14.97 & 2482 \\
\hline
\end{tabular}

Source of data: based on existing data.

activities under the conditions of domestic transportation costs. The more domestic transportation costs are, the more concentrated economic activities. [40] found that when the degree of regional integration is low, through data simulation, the infrastructure is relatively backward, and the transportation cost is large, when the degree of trade liberalization is low, the economic activities are scattered in space; The trade is free, when the degree of globalization increases, the domestic economic activities have a core-edge structure, and economic activities gradually gather in the coastal areas. In this paper, the sum of highway mileage and railway mileage, that is used to indicate the infrastructure level of the province, divides the administrative division area of the province. Due to the different transportation capacity of highways and railways, the data is converted according to the ratio of 1:4.27 [41]. The number of highway mileage $(\mathrm{km})$, railway mileage $(\mathrm{km})$ and administrative division $\left(\mathrm{km}^{2}\right)$ are derived from the China Statistical Yearbook and the statistical yearbooks of various provinces and cities.

Regional protectionism $\left(G o v_{i t}\right)$. According to the indicators proposed by Sun (2013), the income tax ratio of each province and city is higher than that of the fiscal revenue, and the proportion of GDP in each province and city is the weight of the national government. The degree of protectionism of a regional government is indicated, and the trade protectionism of a certain province is stronger. The province's enterprises will have more preferential policies, which will hinder the free circulation of the economy between provinces and cities, thus affecting the economic spatial pattern. LOCP $_{i t}$ represents the degree of protectionism in each province and city, $y_{i t}$ is the total production value of provinces and cities, $Y_{t}$ is the national gross domestic product, $t_{i t}, T_{i t}$ are the corporate income tax and the general budget fiscal revenue of each province and city. The required data are derived from the China Statistical Yearbook and the China Financial Yearbook.

$$
L O C P_{i t}=\frac{y_{i t}}{Y_{t}} * \frac{t_{i t}}{T_{i t}}
$$


Human capital $\left(H u m_{i t}\right)$. The paper uses the number of people per 100,000 people in higher education in each province and city. The data comes from the China Statistical Yearbook.

Distance to the port $\left(D i s_{i t}\right)$. The transportation cost is related to the location of each city. The shorter the product transportation distance is to the international market, the more outward-oriented enterprises gather in the coastal areas to save transportation costs, thus forming a gathering center with location advantage [42]. The geographical distance reflects the transportation cost of the product to a certain extent. This paper selects the top 10 ports of China's import and export to take away from the provinces nearest port distance to the impact of the international market, is generally believed that the closer the distance area, the greater the impact of the international market by. The required distance is calculated by Arcgis, which is the linear distance from the provincial cities of the provinces and cities.

Domestic market potential $\left(M p_{i t}\right)$. This paper is based on the market potential index proposed by Harris (1954), $M P_{i t}=\frac{Y_{i t}}{d_{i i}}+\sum_{i \neq i}^{N} \frac{Y_{j t}^{\delta}}{d_{i j}}$, among that, $M P_{i t}$ is the market potential of the provinces over the years, $Y_{i t}, Y_{j t}$ is the province's total annual GDP, $d_{i i}$ is its own area, $d_{i j}$ is the distance between provinces and cities, is the linear distance of the capital city measured by ArcGis software, $\delta=1.5$ is the calculation of the distance between cities, according to Hering and Poncet (2010), the calculation of the distance between provinces and cities in China. The market potential reflects the economic scale of the domestic market. The economic scale of each province is affected by the market itself and other provinces and cities. It is generally believed that the larger the market size of a certain region indicates that the region is greatly affected by the domestic market. The final impact on economic activity depends on the combined role of the domestic market and the international market.

\section{The Empirical Results of Spatial Model}

\subsection{Overall Spatial Measurement Results}

Moran index (Moran 'I) is the measurement of spatial correlation region generally, the global Moran index shows overall spatial autocorrelation, which is 0.161 , There is a significant positive spatial correlation between regions. Therefore, the spatial econometric model can be applied to this paper. Then the LM test is used to select the spatial error model and the spatial lag model. The LM test results of the spatial lag model and the spatial error model are both significant, and the modified LM test is used. The results show that the spatial lag model is not significant. The sample in this paper is applicable to the spatial error model. To ensure the robustness of the results, the empirical results of the two models are given. As shown in Table 2, 1) a simple least squares model, 2) an individual fixed effect model, 3) a spatial autocorrelation lag model, 4) a 
Table 2. Overall spatial measurement results.

\begin{tabular}{|c|c|c|c|c|c|c|}
\hline & (1) & (2) & (3) & (4) & (5) & (6) \\
\hline & OLS & $\mathrm{FE}$ & SAR & SEM & SAR & SEM \\
\hline \multirow[t]{2}{*}{ lnopen } & 0.222 & $0.458^{\star * *}$ & 0.180 & 0.251 & 0.072 & 0.238 \\
\hline & $(1.05)$ & $(4.95)$ & $(0.81)$ & $(1.06)$ & $(0.33)$ & $(1.04)$ \\
\hline \multirow[t]{2}{*}{ lngov } & $0.209^{* * *}$ & $0.0327^{* *}$ & $0.220^{\star * *}$ & $0.210^{\star * *}$ & $0.270^{* * *}$ & $0.250^{* * *}$ \\
\hline & $(9.10)$ & $(2.33)$ & $(9.12)$ & $(8.59)$ & $(10.89)$ & $(10.14)$ \\
\hline \multirow[t]{2}{*}{ lnhum } & 0.092 & $-0.166^{* * *}$ & $0.132^{\star * *}$ & 0.066 & $0.189^{* *}$ & 0.101 \\
\hline & $(1.44)$ & $(-6.61)$ & (1.99) & $(0.90)$ & $(2.92)$ & $(1.41)$ \\
\hline \multirow[t]{2}{*}{ lntransp } & $-0.176^{* * *}$ & $-0.0343^{\star *}$ & $-0.207^{\star * *}$ & $-0.099^{* * *}$ & $-0.193^{\star \star \star}$ & $-0.076^{*}$ \\
\hline & $(-4.72)$ & $(-2.60)$ & $(-5.26)$ & $(-2.63)$ & $(-5.04)$ & $(-2.01)$ \\
\hline \multirow[t]{2}{*}{ lnopenhum } & -0.020 & $0.133^{\star * *}$ & -0.015 & -0.021 & 0.010 & -0.008 \\
\hline & $(-0.70)$ & $(4.82)$ & $(-0.512)$ & $(-0.67)$ & $(0.35)$ & $(-0.27)$ \\
\hline \multirow[t]{2}{*}{ lnopengov } & $0.079^{* * *}$ & $-0.0542^{* * *}$ & $0.088^{* * *}$ & $0.060^{* * *}$ & $0.103^{* * *}$ & $0.079^{* * *}$ \\
\hline & $(6.61)$ & $(-5.09)$ & $(6.81)$ & $(4.75)$ & $(7.96)$ & (6.09) \\
\hline \multirow[t]{2}{*}{ lnopentransp } & 0.003 & $0.0218^{* * *}$ & -0.003 & $0.036^{*}$ & -0.004 & $0.038^{*}$ \\
\hline & $(0.16)$ & $(2.80)$ & $(-0.17)$ & $(2.08)$ & $(-0.26)$ & $(2.22)$ \\
\hline \multirow[t]{2}{*}{ lndis } & & & & & $0.089^{* * *}$ & $0.088^{\star * *}$ \\
\hline & & & & & $(5.88)$ & $(5.72)$ \\
\hline \multirow[t]{2}{*}{$\operatorname{lnmp}$} & & & & & -0.005 & -0.009 \\
\hline & & & & & $(-0.33)$ & $(-0.55)$ \\
\hline \multirow[t]{2}{*}{$\mathrm{W}^{\star}$ dep.var./spat.aut. } & & & $-0.236^{* *}$ & $0.603^{* * *}$ & & $0.587^{\star \star *}$ \\
\hline & & & $(-2.03)$ & $(8.78)$ & & $(8.22)$ \\
\hline \multirow[t]{2}{*}{ _cons } & $-1.599^{* * *}$ & $0.0259^{* * *}$ & & & $-0.236^{*}$ & \\
\hline & $(-3.31)$ & $(5.10)$ & & & $(-2.09)$ & \\
\hline $\mathrm{n}$ & 480 & 480 & 480 & 480 & 480 & 480 \\
\hline
\end{tabular}

$\operatorname{Chi} 2(7)=(\mathrm{bB})^{\prime}\left[\left(V_{-} \mathrm{b}-\mathrm{V} \_\mathrm{B}\right)^{\wedge}(-1)\right](\mathrm{bB})=32.80$, Prob $>$ chi2 $=0.0000$; t statistics in parentheses; ${ }^{\star} \mathrm{p}<0.1,{ }^{* *} \mathrm{p}<0.05,{ }^{* * *} \mathrm{p}<0.01$.

spatial error model for spatial fixed effects, 5) a spatial autocorrelation model for considering port distance and market potential, 6) a spatial error model considering port distance and market potential.

It can be seen from Table 2, overall, whether it is the least squares estimation or the spatial error model, there is no significant direct correlation between the trade openness and the Gini coefficient. The spatial error model is tested on the sample, find that correlation coefficient is 0.605 , indicating that there is a positive spatial correlation of the residuals; and the correlation coefficient of the spatial autocorrelation model is -0.236 , indicating that the provinces in China have a negative economic correlation as a whole. Considering the influence of the domestic market and the international market, based on the basic model, this paper introduces the port distance and the domestic market potential, and tests 
the robustness of the model. The seventh and eighth columns of Table 2 respectively give the results of space auto-correlation and spatial error test.

Under empirical analysis to the whole 30 provinces in China, not taking into account any fixed effects, the trade openness and space Gini coefficient has no significant correlation; in the case of only considering individual fixed effects, trade openness and the Gini coefficient positive correlation is presented. Under the spatial fixed effect, both the spatial lag model and the spatial Dubin model show that there is no significant correlation between them, and there is no significant correlation when considering the domestic market potential. The spatial error model measurement results show that the cross-term coefficient of trade openness and regional protectionism and infrastructure level is significant, that is, the overall foreign trade mainly affects the spatial distribution of economic activities through regional policy advantages and infrastructure level. The spatial protection of regional protectionism and economic activity has a significant positive correlation coefficient. The protectionist policies of cities within the provinces and cities are different. On the one hand, protectionism will hinder the free flow of economic activities between provinces and cities. On the other hand, provinces and cities with dominant policies of some internal cities will attract more enterprises, to be more concentrated in space. The empirical results show that the increase in regional protectionism will make economic activities more concentration and more international trade in the region, strengthening regional protectionism will lead to the further concentration of economic activity, but its direct role in promoting the economy is far greater than the indirect effect; the infrastructure level has a significant negative correlation with the spatial Gini coefficient, and its cross term with trade openness has a positive correlation coefficient and is significant at the $90 \%$ level. The improvement of infrastructure level is conducive to reducing the transportation cost of enterprises and expanding the scale of the market, thus making the economic activities more dispersed in space. In areas with more open trade, more enterprises, in order to reduce production, will tend to choose the international market. Costs and access to more market information will increase the concentration of companies (Melitz, 2003). The coefficient of human capital is not significant, and it is shown as a positive contribution to the spatial Gini coefficient in the spatial autocorrelation model.

It can be seen from the empirical results of (6) and (7) that the introduction of port distance and domestic market potential has little effect on the coefficients of other variables, and the domestic market potential has no significant correlation with the spatial Gini coefficient, but has a significant distance to the port. The positive correlation is expressed as a significant level of $99 \%$. That is, when the provinces and cities are closer to the port, the internal economic activities of the provinces and cities are more concentrated in space, and vice versa.

\subsection{The Space of Three Regions' Econometric Model}

It can be seen from the literature review that the influence of trade openness on 
the spatial distribution of economic activities is affected by geographical location, and different regions have different spatial correlations. Therefore, it is necessary to explore the influence of trade openness in eastern, central and western regions on economic agglomeration. Table 3 shows the three regions' Moran 'I index showed significant spatial correlation, the space correlation in the middle is above the other two regions, LM test shows that the eastern region is suitable for spatial lag model and spatial error model, the former correction coefficient is significantly lower than the latter. Central and western regions for space-error model, and revised LM test also showed significant spatial error model.

It can be seen from Table 4 that the spatial autocorrelation coefficients of the spatial error models in the eastern, central and western regions are significant, indicating that there is a positive spillover effect between provinces and cities. After controlling the spatial correlation between provinces and cities, except for the central region, there is a significant positive correlation between the trade openness and the spatial Gini coefficient in the eastern and the western. Trade openness, regional protectionism and infrastructure level have promoted the spatial agglomeration of economic activity in the eastern region, and the promotion of trade openness is far greater than the other two factors. As the main area of China's international trade, the eastern region has a natural advantage close to the international market. As foreign trade continues to deepen, the economic activities of the eastern provinces and cities will tend to gather in several prefecture-level cities. There is a significant negative correlation between human capital and the Gini coefficient in the eastern space. The human capital of this paper is expressed as the proportion of the total number of people in higher education. That is, when the education level of people in a certain area is improved, the location of enterprises will be more dispersed. The central region has significant spatial positive correlation, but trade openness does not have a significant correlation with economic agglomeration. The main factors affecting spatial agglomeration are market size and infrastructure level, and the two are negatively correlated with economic agglomeration. The central region has a special geographical location, has a large domestic market, and is also affected by the international market, and finally achieves a balance between the cost and benefit options of the two markets. The western region of space lag model shows a significant positive correlation between the provinces, gathered for trade openness has a positive effect, and higher than the eastern region, the market size for the positive effects of economic agglomeration, when the western economy market size increases, overall economic activity is more concentrated in space. Trade protectionism is the same as the eastern region, and the coefficient is significantly positive. The Western Region's superior policies will also promote the spatial agglomeration of economic activities. The western human capital has a significant positive effect on the spatial Gini coefficient. The infrastructure level has a significant negative effect on the spatial Gini coefficient. The improvement of the infrastructure level makes the western economic activities more spatially dispersed. 
Table 3. Three regions' spatial correlation test.

\begin{tabular}{ccccccc}
\hline \multirow{2}{*}{ Test } & \multicolumn{2}{c}{ East } & \multicolumn{2}{c}{ Central } & \multicolumn{2}{c}{ West } \\
\cline { 2 - 7 } & OLS & $\mathrm{p}$ value & Test value & $\mathrm{p}$ value & Test value & $\mathrm{p}$ value \\
\hline Moran' I & $0.344^{* * *}$ & 0.000 & $0.392^{* * *}$ & 0.000 & $0.342^{* * *}$ & 0.000 \\
LM-error & $93.5663^{* * *}$ & 0.000 & $68.0443^{* * *}$ & 0.000 & $50.9419^{* * *}$ & 0.000 \\
LM-lag & $77.9205^{* * *}$ & 0.000 & -207.3089 & 1.000 & -4.1734 & 1.000 \\
R LM-error & $18.4348^{* * *}$ & 0.000 & $262.0604^{* * *}$ & 0.000 & $53.9806^{* * *}$ & 0.000 \\
R LM-lag & $2.789^{*}$ & 0.095 & -13.2928 & 1.000 & -1.1347 & 1.000 \\
\hline
\end{tabular}

Data source: Matlab R2014 space measurement software package operation results.

Table 4. Results of spatial measurement analysis of the three regions.

\begin{tabular}{|c|c|c|c|c|}
\hline & \multicolumn{2}{|c|}{ East } & \multirow{2}{*}{$\begin{array}{c}\text { Central } \\
\text { SEM }\end{array}$} & \multirow{2}{*}{$\begin{array}{l}\text { West } \\
\text { SEM }\end{array}$} \\
\hline & SAR & SEM & & \\
\hline \multirow[t]{2}{*}{ Lnopen } & $0.920^{\star * *}$ & $1.306^{* * *}$ & -0.023 & $2.601^{* * *}$ \\
\hline & $(2.29)$ & $(2.93)$ & $(-0.023)$ & $(5.51)$ \\
\hline \multirow[t]{2}{*}{ Lnhum } & $0.173^{\star * *}$ & $-0.228^{\star * *}$ & 0.242 & $0.252^{* *}$ \\
\hline & $(4.95)$ & $(-2.85)$ & $(0.64)$ & $(2.40)$ \\
\hline \multirow[t]{2}{*}{ Lntransp } & -0.079 & $0.120^{\star *}$ & $-0.58^{\star *}$ & $-0.958^{* * *}$ \\
\hline & $(-1.31)$ & $(2.08)$ & $(-3.17)$ & $(-5.62)$ \\
\hline \multirow[t]{2}{*}{ Lngov } & 0.013 & $0.195^{\star * *}$ & 0.201 & $0.161^{\star *}$ \\
\hline & $(0.34)$ & $(5.48)$ & $(0.76)$ & $(1.97)$ \\
\hline \multirow[t]{2}{*}{ Lnopenhum } & -0.009 & $-0.135^{\star *}$ & -0.0 .11 & $0.156^{* * *}$ \\
\hline & $(-0.42)$ & $(-2.26)$ & $(-0.08)$ & $(6.29)$ \\
\hline \multirow[t]{2}{*}{ Lnopentransp } & $-0.101^{*}$ & $0.118^{\star *}$ & $-0.176^{\star *}$ & $-0.308^{\star * *}$ \\
\hline & $(-1.92)$ & $(2.49)$ & $(-2.52)$ & $(-4.90)$ \\
\hline \multirow[t]{2}{*}{ Lnopengov } & $0.102^{* * *}$ & $0.133^{* * *}$ & 0.060 & $0.099^{* *}$ \\
\hline & $(3.40)$ & $(4.01)$ & $(0.59)$ & $(2.40)$ \\
\hline \multirow[t]{2}{*}{ Lnmp } & $0.088^{\star *}$ & 0.037 & $-0.097^{\star * *}$ & $0.123^{* * *}$ \\
\hline & $(2.05)$ & $(1.36)$ & $(-3.17)$ & $(3.53)$ \\
\hline \multirow[t]{2}{*}{ Spat.aut. } & $0.448^{* * *}$ & $0.718^{\star * *}$ & $0.741^{\star * *}$ & $0.648^{* * *}$ \\
\hline & $(5.98)$ & $(14.33)$ & (15.98) & $(10.55)$ \\
\hline$N$ & 192 & 192 & 144 & 144 \\
\hline
\end{tabular}

Chi2 $(7)=(\mathrm{bB})^{\prime}\left[\left(\mathrm{V}_{-} \mathrm{b}-\mathrm{V}_{-} \mathrm{B}\right) \wedge(-1)\right](\mathrm{bB})=32.80$ Prob $>$ chi2 $=0.0000, \mathrm{t}$ statistics in parentheses; ${ }^{*} \mathrm{p}<0.1$, ${ }^{* *} \mathrm{p}<0.05,{ }^{* * *} \mathrm{p}<0.01$.

From the mechanism, the international trade mainly affects the central area of the spatial pattern by the infrastructure level, the area of lower infrastructure level, where foreign trade more gathering. The eastern and western regions of the three kinds of mechanisms were significant, higher degree of protectionism area of the region, increase foreign trade makes more economic activity gather- 
ing. Generating international trade policy to promote national development, tariffs and other trade barriers affecting the major part of the cost of trade, to improve the trading environment will be more cooperation and trade policy agreements between the countries, while causing domestic trade policy changes in the environment. Domestic part of the region in the international trade environment, facing pressure from international competition, in order to improve the region's interests, as the main supply system of government has the power to change the backward system, around the legal, policy, management, and design the new system, out of the old institutions that improve institutional efficiency to protect the region's industries and stimulate foreign trade. The policy cost allows enterprises in a certain region to enjoy more favorable conditions, and the preferential policies of the special economic zones have attracted a large number of enterprises. If the regional scope continues to be magnified, regional special economic management and preferential policies, tax relief, and good infrastructure and other policy benefits will greatly reduce regional foreign trade costs and increase trade freedom (Coşar, 2016). The influence of the level of foreign trade in the eastern region on the concentration of regional economic activities, the more diversified economic activities through human capital, the mechanism effect of the infrastructure level and human capital in the western region is just the opposite of that in the eastern region.

\section{Results and Policy Recommendations}

\subsection{Results}

From the empirical results, regardless of whether to consider space-efficient, in terms of the overall data and the eastern and western regions, regional protectionism and regional agglomeration which have a significant positive impact on the whole market economy of China still needs to be improved, the coastal areas have more policy advantages, and this policy advantage is also increasing the regional gap in China. On the whole, the international market for the spatial distribution of economic activity in China is greater than the impact of the domestic market, and the empirical results show a significant distance to the port of promoting into action, while the domestic market potential has no significant correlation.

When participating in the international market, companies need a more skilled workforce and strengthen the demand for professional knowledge talents. Human capital is concentrated in a part of the region driven by demand. Higher education talents are the source of innovation. The transformation and upgrading of industries cannot be separated from the research and development of relevant technical personnel. Foreign trade promotes the concentration of human capital. In order to enjoy the convenience of "labor pool", space agglomeration has become an important choice for enterprise development. The region which has the advantage of the elements to a certain extent is more likely to be a 
gathering center, with the development of reform and opening up, the eastern coast of China acquired better international market environment, which caused movement of labor with cities, restructuring of industrial structure, promotion of technology and higher education. The increasing in the number of people makes their more dispersed spatially, so as to reduce the homogenization competition and promote the spread of enterprises. The western region does not have an advantage in human resources, and the increase in the level of higher education has an agglomeration effect on economic activities.

\subsection{Policy Recommendations}

Promote the development of the market economy and break down regional policy barriers. Under the trend of globalization and economic integration, the Chinese economy and the world economy becoming increasingly close, all regions should optimize the industrial structure, restructure economic, develop high-tech industries and services, and improve industrial competitiveness. China has entered the new normal economy environment. All regions should respond to supply-side reforms and be closely linked to the transformation of the country's economic structure. Based on the leading industries and characteristic industries in each region, develop innovative industries and technologies to strengthen the city's competitiveness. With the continuous deepening of the regional integration process, various countries have a wide range of international economic cooperation and various forms. Therefore, governments and enterprises should actively respond and strive to broaden the scope of cooperation and cooperation with other countries and regions.

Imply differentiated trade policies and promote coordinated regional development. In light of the actual situation of China's economic development and the special political environment, drawing on the successful experience of economic cooperation in other countries or regions, we will formulate strategic plans for participating in international economic cooperation and do a good job in deployment. Select the partner timely, different regions of partner selection according to its own characteristics, widening the breadth of participation in international trade, in order to meet the timely needs of each region and to ease international pressure.

Increase investment in human capital and enhance the vitality of regional innovation. China is actively promoting curriculum reform to improve the quality of personnel training. All regions should actively respond to national policies and attach importance to the cultivation of talents. All regions should formulate policies tailored to local conditions, cultivate differentiated talents, and attract more outstanding talents to drive the accumulation of intellectual capital throughout the region. Emphasis on capital innovation and market research and development, providing more financial and policy support for social innovation institutions such as research institutes and incubators, and creating a more open economic environment for talents. 


\section{Conflicts of Interest}

The author declares no conflicts of interest regarding the publication of this paper.

\section{References}

[1] Fujita, M. and Hu, D. (2001) Regional Disparity in China 1985-1994: The Effects of Globalization and Economic Liberalization. The Annals of Regional Science, 35, 3-37. https://doi.org/10.1007/s001680000020

[2] Fally, T., Paillacar, R. and Terra, C. (2010) Economic Geography and Wages in Brazil: Evidence from Micro-Data. Journal of Development Economics, 91, 155-168. https://doi.org/10.1016/j.jdeveco.2009.07.005

[3] Wen, W.D. and Zhai, G.M. (2014) Spatial Agglomeration and Export of China's Manufacturing Industry: Based on Enterprise Level Research. Management World, No. 10, 57-74.

[4] Allen, T. and Arkolakis, C. (2014) Trade and the Topography of the Spatial Economy. The Quarterly Journal of Economics, 129, 1085-1140. https://doi.org/10.1093/qje/qju016

[5] Henderson, J.V. (1982) Systems of Cities in Closed and Open Economies. Regional Science and Urban Economics, 12, 325-350. https://doi.org/10.1016/0166-0462(82)90022-9

[6] Alonso-Villar, O. (2001) Large Metropolises in the Third World: An Explanation. Urban Studies, 38, 1359-1371. https://doi.org/10.1080/00420980120061070

[7] Brülhart, M. (2011) The Spatial Effects of Trade Openness: A Survey. Review of World Economics, 147, 59-83. https://doi.org/10.1007/s10290-010-0083-5

[8] Krugman, P. (1980) Scale Economies, Product Differentiation, and the Pattern of Trade. The American Economic Review, 70, 950-959.

[9] Krugman, P. (1991) Increasing Returns and Economic Geography. Journal of Political Economy, 99, 483-499. https://doi.org/10.1086/261763

[10] Krugman, P. and Elizondo, R.L. (1996) Trade Policy and the Third World Metropolis. Journal of Development Economics, 49, 137-150. https://doi.org/10.1016/0304-3878(95)00055-0

[11] Melitz, M.J. (2003) The Impact of Trade on Intra-Industry Reallocations and Aggregate Industry Productivity. Econometrica, 71, 1695-1725. https://doi.org/10.1111/1468-0262.00467

[12] Paluzie, E. (2001) Trade Policy and Regional Inequalities. Papers in Regional Science, 80, 67-85. https://doi.org/10.1007/PL00011492

[13] Ades, A.F. and Glaeser, E.L. (1995) Trade and Circuses: Explaining Urban Giants. The Quarterly Journal of Economics, 110, 195-227. https://doi.org/10.2307/2118515

[14] Nitsch, V. (2006) Trade Openness and Urban Concentration: New Evidence. Journal of Economic Integration, 21, 340-362.

[15] Kandogan, Y. (2014) The Effect of Foreign Trade and Investment Liberalization on Spatial Concentration of Economic Activity. International Business Review, 23, 648-659. https://doi.org/10.1016/j.ibusrev.2013.11.005

[16] Hanson, G.H. (2001) US-Mexico Integration and Regional Economies: Evidence from Border-City Pairs. Journal of Urban Economics, 50, 259-287. https://doi.org/10.1006/juec.2001.2217 
[17] Sjöberg, Ö. and Sjöholm, F. (2004) Trade Liberalization and the Geography of Production: Ag-Glomeration, Concentration, and Dispersal in Indonesia's Manufacturing Industry. Economic Geography, 80, 287-310. https://doi.org/10.1111/j.1944-8287.2004.tb00236.x

[18] Dix-Carneiro, R. and Kovak, B.K. (2017) Trade Liberalization and Regional Dynamics. American Economic Review, 107, 2908-2946. https://doi.org/10.1257/aer.20161214

[19] Koenig, P. (2009) Agglomeration and the Export Decisions of French Firms. Journal of Urban Economics, 66, 186-195. https://doi.org/10.1016/j.jue.2009.07.002

[20] Zhou, K. (2016) Agglomeration and Export: Theory, Facts and Interpretation. Jinan University.

[21] Fernández, C. (2015) Agglomeration and Trade: The Case of Colombia. Artículos de re-vista.

[22] Jin, Y., Chen, W. and Lu, M. (2006) Regional Industrial Agglomeration in China: Economic Geography, New Economic Geography and Economic Policy. Economic Research, No. 4, 79-89.

[23] Akkemik, K.A. and Göksal, K. (2014) Do Exports Explain Industrial Agglomeration and Regional Disparities in Turkey? Journal of International Development, 26, 471-491. https://doi.org/10.1002/jid.1783

[24] Egger, P., Huber, P. and Pfaffermayr, M. (2005) A Note on Export Openness and Regional Wage Disparity in Central and Eastern Europe. The Annals of Regional Science, 39, 63-71. https://doi.org/10.1007/s00168-004-0202-0

[25] Fujita, M., Krugman, P.R., Venables, A.J., et al. (1999) The Spatial Economy: Cities, Regions and International trade. MIT Press, Cambridge, MA.

[26] He, C., Guo, Q. and Ye, X. (2016) Geographical Agglomeration and Co-Agglomeration of Exporters and Non-Exporters in China. GeoJournal, 81, 947-964. https://doi.org/10.1007/s10708-015-9640-8

[27] Zhao, T. and Jin, X.R. (2011) Research on the Spillover Effect of Export Agglomeration Growth, Foreign Direct Investment and Export Trade. Zhejiang Social Sciences, No. 6, 16-25+155.

[28] Coşar, A.K. and Fajgelbaum, P.D. (2016) Internal Geography, International Trade, and Regional Specialization. American Economic Journal: Microeconomics, 8, 24-56. https://doi.org/10.1257/mic.20140145

[29] Guevara-Rosero, G.C. (2017) The Effect of Trade on Agglomeration within Regions. Journal for Economic Forecasting, No. 1, 75-97.

[30] Tu, Y.M. (2015) Affect Manufacturing Export Trade of Industrial Agglomeration of Study-Based on New Economic Geography. Reform and Opening Up, No. 21, 22-24.

[31] Yao, D. and Mao, Ch. (2013) Research on the Impact of International Trade on Regional Urban-Rural Income Gap in China. International Business. Journal of University of International Business and Economics, No. 2, 15-25.

[32] Luo, Y.Ch. and Gu, R.X. (2014) The Spatial Agglomeration Pattern of China's Manufacturing Industry from 1980 to 2011 and Its Evolution Trends. Economic Geography, 34, 82-89.

[33] Midelfart-Knarvik, K.H., Overman, H.G. and Venables, A. (2001) Comparative Advantage and Economic Geography: Estimating the Determinants of Industrial Location in the EU.

[34] Ge, Y. (2009) Globalization and Industry Agglomeration in China. World Devel- 
opment, 37, 550-559. https://doi.org/10.1016/j.worlddev.2008.07.005

[35] Shao, W. (2012) Research on the Impact of Foreign Trade on China's Manufacturing Industry Cluster. Jilin University, Changchun.

[36] Zhang, C. and Zhao, W. (2009) Opening with Chinese Industrial Agglomeration: Mechanism and Empirical Analysis. International Trade, No. 9, 89-96.

[37] Yao, P. (2016) How Does Trade Openness Affect the Spatial Layout of Economic Activities? Theory and Empirical Evidence in China. World Economic Papers, No. 6, 75-89.

[38] Deng, R.B. and Liu, Y. (2016) Industrial Agglomeration, Spatial Spillover and Regional Economic Growth-Study Space Panel Doberman Model. Into Economic Issues, No. 1, 66-76.

[39] Bao, Q., Shao, M. and Li, G.S. (2012) Differences between Geographical Agglomeration, Industry Concentration and Chinese Enterprises' Export Models. Management World, No. 9, 61-75.

[40] Wang, J. and Zheng, X.P. (2013) Industrial Agglomeration: Asymmetry of Regions and Trade Costs. Review of Urban \& Regional Development Studies, 25, 61-78.

[41] Yao, S.J. and Wei, K.L. (2008) An Interactive Empirical Analysis of China's Economic Growth, Foreign Direct Investment and Export Trade. Economics (Quarterly), No. 1, 151-170.

[42] Xu, D.Y. and Liang, Q. (2012) Trade Cost and Domestic Industrial Geography. Economics (Quarterly), 11, 1113-1136. 